
RESEARCH AND DEVELOPMENT

\author{
http://journal.unnes.ac.id/sju/index.php/higeia
}

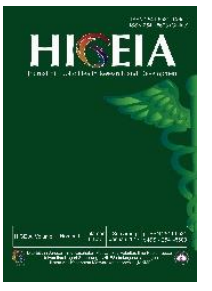

\title{
MANAJEMEN PROGRAM PELAYANAN VOLUNTARY COUNSELING AND TESTING (VCT)
}

\author{
M. Husni Ari Santoso ${ }^{\bowtie}$, Bambang Wahyono \\ Administrasi Kebijakan Kesehatan, Jurusan Ilmu Kesehatan Masyarakat, \\ Fakultas Ilmu Keolahragaan, Universitas Negeri Semarang
}

\section{Info Artikel}

Sejarah Artikel:

Diterima Februari 2018

Disetujui Maret 2018

Dipublikasikan April

2018

\section{Keywords:}

Management, Program, VCT

\begin{abstract}
Abstrak
Kasus HIV di Kota Semarang tahun 2015 mengalami kenaikan sebesar 0,66\% dibandingkan tahun 2014. Jumlah kunjungan pasien VCT Puskesmas Lebdosari Kota Semarang selama tahun 2016 mengalami fluktuasi dengan jumlah kunjungan sebanyak 200 pasien. Tujuan penelitian ini adalah untuk mengetahui gambaran manajemen program pelayanan VCT di Puskesmas Lebdosari Kota Semarang. Metode penelitian ini adalah metode penelitian kualitatif dengan jenis penelitian menggunakan penelitian deskriptif kualitatif. Hasil penelitian menunjukkan bahwa sumber daya manusia dan sarana cukup, tidak ada dana alokasi khusus untuk pelaksanaan program pelayanan VCT, metode pelaksanaan cenderung menggunakan VCT statis, pemasaran VCT dengan melakukan penyuluhan, perencanaan VCT dilakukan oleh bagian UKM dan UKP, pembagian tugas dan wewenang dalam pengorganisasian VCT dilakukan berdasarkan petugas yang mengikuti pelatihan, tahapan pelayanan VCT sudah sesuai dengan pedoman, evaluasi VCT hanya sebatas laporan, dan jumlah kunjungan pasien dalam beberapa bulan terakhir cenderung menurun. Simpulan penelitian ini adalah gambaran manajemen program pelayanan VCT dapat dikatakan cukup.
\end{abstract}

\begin{abstract}
Cases of HIV in Semarang City in 2015 increased by 0.66\% compared to 2014. The number of VCT patient visits to Lebdosari Public Helath Center Semarang City during 2016 fluctuated with the number of visits 200 patients. The research purposed to know the description of VCT service program management at Lebdosari Public Health Center Semarang City. This research method was qualitative research method with research type using qualitative descriptive research. The results showed that human resources and facilities were adequate, no special allocation fund for VCT implementation, implementation method tends to use static VCT, VCT marketing by doing counseling, VCT planning done by SME and UKP division, division of task and authority in organizing VCT was performed on the basis of the training officers, the VCT service stage was in accordance with the guidelines, VCT evaluation was only limited to the report, and the number of patient visits in recent months tends to decrease. The conclusion was the description of VCT service program management was sufficient.
\end{abstract}

E-mail: ari.husnie@gmail.com 


\section{PENDAHULUAN}

Berdasarkan Peraturan Menteri Kesehatan Republik Indonesia nomor 21 tahun 2013 tentang penanggulangan HIV dan AIDS, untuk pemeriksaan diagnosis HIV dapat dilakukan dengan konseling dan Tes HIV Sukarela atau Voluntary Counseling and Testing (VCT). VCT merupakan proses konseling sukarela dan tes HIV atas inisiatif individu yang bersangkutan. VCT dilakukan dengan langkahlangkah meliputi konseling pra tes, tes HIV, dan konseling pasca tes. Penyelenggaraan pelayanan VCT terdapat standar minimum yang mencakup seperti sumber daya manusia yang sudah terlatih dan kompeten, sarana dan prasarana yang cukup, dan pembiayaan berdasarkan unit cost yang proporsional.

Jumlah pelayanan Voluntary Counseling and Testing (VCT) terus mengalami peningkatan. Dilihat dari profil kesehatan Indonesia, jumlah layanan Voluntary Counseling and Testing (VCT) di Indonesia tahun 2015 sebanyak 2.221 dan untuk wilayah Provinsi Jawa Tengah sebanyak 333. Semakin meningkatnya jumlah layanan Voluntary Counseling and Testing (VCT) ini berarti semakin terbukanya akses kebutuhan akan informasi mengenai kesehatan.

Data dari Kementerian Kesehatan Indonesia melaporkan jumlah kasus baru HIV positif yang dilaporkan pada tahun 2015 sebanyak 30.935 kasus, menurun dibandingkan tahun sebelumnya. Akan tetapi dari tahun 2011 sampai dengan tahun 2014 jumlah kasus baru HIV positif selalu mengalami peningkatan (Kementerian Kesehatan RI, 2016).

Di Provinsi Jawa Tengah kasus HIV meningkat dari tahun 2013 sampai dengan tahun 2015. Adapun jumlah kasus secara berturut-turut dari tahun 2013 sejumlah 1.219, 1.399 pada tahun 2014, dan 1.467 di tahun 2015. Bila dilihat berdasarkan umur, penderita HIV dapat menimpa umur dari usia dini hingga tua. Penderita HIV terbanyak berturut-turut yaitu umur 25-49 tahun sebesar 70,69 persen, kemudian umur 20-24 tahun sebesar 13,91 persen dan umur diatas 50 tahun 7,57 persen (Dinas Kesehatan Provinsi Jawa Tengah, 2015).
Berdasarkan profil kesehatan Kota Semarang tahun 2015, di Kota ini kasus HIV mengalami peningkatan dibandingkan dengan tahun 2014. Jumlah penemuan kasus pada tahun 2015 yaitu sebesar 456 kasus (0,66\%). Data diatas merupakan data kasus HIV yang ditemukan di Kota Semarang dari laporan klinik VCT, sehingga bukan hanya warga Kota Semarang namun juga luar wilayah Kota Semarang. Sedangkan data untuk kasus HIV tahun 2015 untuk Kota Semarang saja sebanyak 151 orang meningkat dari tahun 2014 yang sejumlah 142 orang dengan kasus HIV. Mengingat hal itu maka diperlukan suatu pencegahan atau penanggulangan mengenai HIV/AIDS (Dinas Kesehatan Kota Semarang, 2015).

Kota Semarang sebagai ibu kota Provinsi Jawa Tengah, tentunya memiliki berbagai sarana pelayanan kesehatan yang tidak sedikit, seperti contohnya saja puskesmas. Puskesmas di Kota Semarang mempunyai jumlah sebanyak 37 puskesmas yang terdiri dari puskesmas perawatan sebanyak 11 dan puskesmas non perawatan sebanyak 26 (Dinas Kesehatan Kota Semarang, 2015).

Salah satu puskesmas di Kota Semarang yang mempunyai layanan Voluntary Counseling and Testing (VCT) adalah Puskesmas Lebdosari. Berdasarkan laporan kunjungan Voluntary Counseling and Testing (VCT) Puskesmas Lebdosari pada tahun 2016, orang yang memanfaatkan layanan Voluntary Counseling and Testing (VCT) sejumlah 600 dan ditemukan kasus HIV positif sejumlah 22. Dari jumlah tersebut sebagian besar terdiri dari perempuan dengan jumlah kasus HIV positif sebesar 13 . Adapun jumlah kunjungan layanan Voluntary Counseling and Testing (VCT) pada empat bulan terakhir dari Bulan September sampai dengan Bulan Desember 2016 cenderung mengalami fase penurunan dan hanya sekali mengalami kenaikan pada Bulan Desember yaitu beruturutturut 167, 148, 82, dan 101 kunjungan.

$$
\text { Puskesmas Lebdosari merupakan }
$$
puskesmas dengan wilayah kerja yang menaungi tempat lokalisasi terbesar di Kota Semarang yang berada di wilayah Kelurahan 
Kalibanteng Kulon. Lokalisasi tersebut menjadi tempat Wanita Pekerja Seks (WPS) dalam menjajakan dirinya. WPS ini merupakan salah satu yang memiliki risiko tinggi terkena HIV/AIDS sehingga memanfaatkan layanan Voluntary Counseling and Testing (VCT) sangatlah penting. Akan tetapi pada kenyataannya, kunjungan Wanita Pekerja Seks (WPS) yang memanfaatkan layanan Voluntary Counseling and Testing (VCT) di Puskesmas Lebdosari cenderung menurun dari Bulan September sampai dengan Bulan Desember 2016, hanya satu kali saja yang mengalami kenaikan di Bulan Desember yaitu beruturut-turut 163, 143, 79, dan 100 kunjungan.

Menurut Usnawatig (2013) WPS mempunyai motivasi yang rendah untuk mengikuti VCT dikarenakan adanya anggapan dari WPS bahwa dirinya tidak berisiko HIV/ AIDS, VCT bukan kebutuhan utama untuk WPS, dan adanya anggapan kurang penting tentang VCT. Melihat hal itu, sebagai puskesmas yang menaungi tempat lokalisasi, tentunya diperlukan manajemen yang baik dalam menjalankan program pelayanan VCT sehingga mampu mempengaruhi WPS atau kelompok berisiko yang lain untuk memanfaatkan layanan VCT.

Hasil penelitian yang dilakukan Mujiati (2013) menyimpulkan bahwa layanan VCT secara umum sudah berjalan lancar, namun beberapa kendala yang masih dihadapi yaitu dari segi konselor (jumlah konselor, waktu tunggu konselor, bahasa dan sikap konselor/petugas), kemudian untuk sarana dan prasarana yang masih kurang diantaranya belum ada ruangan khusus VCT, tidak ada tempat cuci tangan di tempat pengambilan darah, dan tidak terdapat papan informasi tentang alur layanan VCT. Sedangkan menurut penelitian Armanita (2008), hambatan operasional dari pelaksanaan pelayanan VCT adalah sebagian petugas belum mengikuti pelatihan VCT sehingga jumlah petugas yang benar-benar melaksanakan VCT masih sedikit sehingga hal ini juga mempengaruhi skill dari petugas terutama dari skill konselingnya.

Peneliti berkeinginan untuk mengadakan penelitian tentang gambaran manajemen program pelayanan Voluntary Counseling and Testing (VCT) di Puskesmas Lebdosari Kota Semarang. Penelitian ini bertujuan untuk mengetahui gambaran manajemen program pelayanan Voluntary Counseling and Testing (VCT) di Puskesmas Lebdosari Kota Semarang.

\section{METODE}

Jenis penelitian ini adalah kualitatif yang penyajian datanya menggunakan pola deskriptif. Penelitian kualitatif dengan metode deskriptif yang dilakukan, bermaksud menggambarkan secara sistematis fakta dan karakteristik suatu objek atau subjek yang diteliti secara tepat dengan lima informan utama dan tiga informan triangulasi yang diperoleh dengan teknik purposive sampling. Cara pemilihan informan penelitian ini tidak didasarkan pada jumlah tetapi berdasarkan prinsip kesesuaian dan prinsip kecukupan. Dalam penelitian ini yang menjadi informan utama yaitu tenaga pelaksana program pelayanan VCT sedangkan untuk informan triangulasi terdiri dari Pegawai Dinas Kesehatan Kota Semarang dan wanita pekerja seks. Penelitian yang dilakukan berfokus pada gambaran manajemen program pelayanan Voluntary Counseling and Testing (VCT) di Puskesmas Lebdosari Kota Semarang yaitu aspek input yang terdiri dari SDM (jumlah, latar belakang pendidikan, pelatihan, hambatan operasional), dana (sumber dana, pemanfaatan dana, kecukupan dana), sarana (jenis sarana, ketersediaan sarana, kondisi dan perawatan sarana, hambatan dalam penyediaan sarana), metode (pengetahuan petugas tentang metode pelaksanaan VCT, pelaksanaan metode pada pelaksanaan VCT), dan market (perencanaan, strategi pemasaran); aspek process yang terdiri dari perencanaan (pelaksanaan kegiatan perencanaan, penyusunan perencanaan), pengorganisasian (koordinator VCT, tugas dan wewenang dalam program VCT), tahapan pelayanan VCT (pengetahuan petugas tentang layanan VCT, kesesuaian pelayanan dengan buku pedoman, prinsip layanan VCT, hambatan 
dalam pelayanan VCT), dan evaluasi Kegiatan; dan aspek output yaitu pasien yang berkunjung ke layanan VCT.

Instrumen dalam penelitian ini adalah peneliti sendiri yang dibantu dengan alat perekam suara yang bertujuan supaya data yang diperoleh dapat tersimpan dengan baik dalam alat perekam suara dan pedoman wawancara. Pedoman wawancara digunakan agar wawancara yang dilakukan tidak menyimpang dari tujuan penelitian.

Teknik pengambilan data dalam penelitian ini dengan cara wawancara mendalam dan studi dokumentasi atau pengumpulan data dengan dokumen. Wawancara yang dilakukan oleh peneliti dibantu dengan panduan wawancara berisi pertanyaan yang digunakan peneliti sebagai acuan dalam menggali informasi dari informan penelitian. Adapun wawancara yang dilakukan oleh peneliti berupa wawancara semi terstruktur dengan tujuan untuk mengumpulkan informasi yang kompleks, yang sebagian besar berisi pendapat, sikap, dan pengalaman pribadi. Sedangkan studi dokumentasi digunakan untuk mengumpulkan data dengan menyelidiki dokumen-dokumen seperti peraturan perundang-undangan yang terkait, profil puskesmas dan dokumen-dokumen yang berhubungan dengan program pelayanan VCT di Puskesmas Lebdosari Kota Semarang. Adapun Pemeriksaan keabsahan data dengan triangulasi yang dipakai adalah triangulasi dengan sumber dan antar teori.

Sumber data primer yang dibutuhkan dalam penelitian ini merupakan hasil wawancara mendalam dari informan utama dan triangulasi. Sedangkan data sekunder dalam penelitian ini yaitu data pelengkap yang diperoleh dari laporan, dokumen, maupun buku teks yang terdapat pada instansi puskesmas maupun pada kepustakaan yang berhubungan dengan masalah penelitian yang dibahas.

Prosedur penelitian terdiri dari tahap pra penelitian, tahap penelitian, dan tahap pasca penelitian. Kegiatan yang dilakukan dalam tahap pra penelitian adalah menyusun rancangan penelitian, memilih lokasi penelitian, mengurus perizinan penelitian, memilih dan menentukan informan, dan menyiapkan perlengkapan penelitian. Prosedur penelitian selanjutnya adalah tahap penelitian dimana peneliti melakukan wawancara mendalam dengan informan utama dan informan triangulasi. Prosedur penelitian yang terakhir adalah tahap pasca penelitian, tahap ini dilakukan dengan menganalisis data-data yang diperoleh selama proses penelitian berlangsung. Setelah dilakukan proses analisis data, dilakukan penarikan kesimpulan penelitian oleh peneliti dengan menggunakan metode-metode tertentu.

Teknik analisis data dalam penelitian ini terdiri dari tiga langkah yaitu reduksi data sebagai proses pemilihan, pemusatan perhatian pada penyederhanaan, pengabstrakan dan tranformasi data kasar yang muncul dari catatan-catatan tertulis di lapangan. Tahap selanjutnya adalah penyajian data, penyajian data kualitatif yang digunakan adalah dalam bentuk uraian singkat dan teks naratif. Tahap yang terakhir adalah penarikan kesimpulan/verifikasi, Penarikan kesimpulan dengan membandingkan pertanyaan penelitian dengan hasil penelitian.

\section{HASIL DAN PEMBAHASAN}

Puskesmas Lebdosari merupakan salah satu Puskesmas Induk non perawatan di Semarang Barat dengan luas tanah $1.087 \mathrm{~m}^{2}$ dan luas bangunan $660 \mathrm{~m}^{2}$ dengan luas wilayah kerja 585,4 ha. Puskesmas Lebdosari berdiri pada tahun 1990. Puskesmas Lebdosari terletak di Jalan Taman Lebdosari Kelurahan Kalibanteng Kulon. Dalam menjalankan peran dan fungsi sebagai Puskesmas Induk, Puskesmas Lebdosari mempunyai 1 (satu) puskesmas pembantu, yaitu Puskesmas Gisik Drono yang berada di Jl. Taman Sri Rejeki Kelurahan Grisik Drono Kecamatan Semarang Barat. Puskesmas Lebdosari mempunyai wilayah kerja yang meliputi empat kelurahan, yaitu Kelurahan Kalibanteng Kulon, Kelurahan Kalibanteng Kidul, Kelurahan Gisik Drono, dan Kelurahan Tambak Rejo. 
Tabel 1. Gambaran Karakteristik Umum Informan Utama dan Informasi Triangulasi

\begin{tabular}{lllll}
\hline $\begin{array}{l}\text { Karakteristik Informan } \\
\text { Utama (IU) }\end{array}$ & $\begin{array}{l}\text { Jenis } \\
\text { Kelamin }\end{array}$ & $\begin{array}{l}\text { Umur } \\
\text { (Tahun) }\end{array}$ & $\begin{array}{l}\text { Pendidikan } \\
\text { Terakhir }\end{array}$ & Jabatan \\
\hline Informan Utama 1 & Perempuan & 35 & D3 & Perawat \\
Informan Utama 2 & Perempuan & 32 & D3 & Analis Kesehatan \\
Informan Utama 3 & Perempuan & 40 & D3 & Perawat \\
Informan Utama 4 & Perempuan & 37 & D3 & Analis Kesehatan \\
Informan Utama 5 & Perempuan & 52 & S2 & Kepala Puskesmas \\
Informan Triangulasi 1 & Perempuan & 28 & S1 & Koordinator Pengelola \\
& & & & Program HIV/AIDS Dinas \\
& & & & Kesehatan Kota Semarang \\
Informan Triangulasi 2 & Perempuan & 35 & SMA & WPS \\
Informan Triangulasi 3 & Perempuan & 35 & SD & WPS \\
\hline
\end{tabular}

Puskesmas Lebdosari mempunyai berbagai macam pelayanan, salah satunya yaitu pelayanan Voluntary Counseling and Testing (VCT). Pelayanan VCT merupakan suatu layanan yang bersifat sukarela untuk mengetahui adanya infeksi HIV di tubuh seseorang. Adapun kegiatannya meliputi konseling pra tes, tes HIV, dan konseling pasca tes. Pelayanan VCT ini dilaksanakan pada hari jam kerja Puskesmas Lebdosari yaitu untuk pendaftaran Senin s.d. Kamis Pukul 07.15 s.d. 12.00 WIB dan pelayanannya Pukul 07.15 s.d. selesai, sedangkan untuk pendaftaran hari Jumat s.d. Sabtu Pukul 07.15 s.d. 10.00 WIB dan pelayanannya pukul 07.15 s.d. selesai.

Berdasarkan tabel 1, informan dalam penelitian ini berjumlah 8 informan. Dari 8 informan tersebut terbagi menjadi 5 informan utama dan 3 informan triangulasi. Informan utama pada penelitian ini merupakan petugas dari program pelayanan Voluntary Counseling and Testing di Puskesmas Lebdosari Kota Semarang. Petugas VCT ini terdiri dari penanggung jawab program VCT, konselor, analis, petugas pencatatan dan pelaporan, dan manajemen kasus. Semua petugas VCT berjenis kelamin perempuan dengan pendidikan terakhir paling rendah yaitu D3 dan paling tinggi yaitu S2 dibidang kesehatan. Adapun rata-rata umur dari semua informan utama yaitu 40 tahun. Sedangkan informan triangulasi pada penelitian ini terdiri dari 1 Koordinator Pengelola Program HIV/AIDS Dinas Kesehatan Kota Semarang dan 2 wanita pekerja seks (WPS). Informan triangulasi juga semuanya berjenis kelamin perempuan dengan pendidikan terakhir paling rendah SD dan paling tinggi yaitu S1.

Sumber daya manusia merupakan kunci pokok yang harus diperhatikan dengan segala kebutuhannya. Sebagai kunci pokok, Sumber daya manusia akan menentukan keberhasilan pelaksanaan kegiatan organisasi (Findarti, 2016). Sumber daya manusia juga merupakan salah satu komponen penting dalam manajemen sebuah program. Tanpa adanya sumber daya manusia, sebuah program tidak dapat berjalan. Program pelayanan VCT harus mempunyai sumber daya manusia yang sudah terlatih dan kompeten.

Berdasarkan hasil penelitian, sumber daya manusia dalam pelaksanaan program pelayanan VCT di Puskesmas Lebdosari terdiri dari 2 konselor, 2 analis, 1 petugas pencatatan dan pelaporan (RR) yang sekaligus merangkap sebagai petugas manajemen kasus. Dari jumlah tersebut, ada perbedaan informasi mengenai jumlah sumber daya manusia pelaksana program pelayanan VCT. Menurut tiga informan utama jumlah sumber daya manusia yang melaksanakan program pelayanan VCT sudah mencukupi, sedangkan dua informan utama lain mengatakan bahwa jumlah sumber daya manusia belum mencukupi yakni pada dokter sebagai konselor. Akan tetapi, jika dilihat dari informasi informan triangulasi bahwa sumber daya manusia dalam pelayanan VCT yang harus ada yaitu konselor dan petugas laboratorium atau analis dan pedoman 
pelayanan VCT yang mengatakan bahwa sumber daya manusia atau petugas pelayanan VCT terdiri dari dua konselor dan petugas laboratorium maka jumlah sumber daya manusia dalam pelaksanaan program pelayanan VCT di Puskesmas Lebdosari sudah mencukupi. Hal ini sejalan dengan penelitian Yuriati (2016) bahwa tenaga kesehatan PMTCT sudah mencukupi dan telah mendapatkan pelatihan. Penelitian lain tentang SDM atau tenaga kesehatan yang dilakukan oleh Sari (2013) pada tenaga yang terlibat dalam pelaksanaan kegiatan program P2DBD di wilayah kerja Puskesmas Tamalanrea mengatakan bahwa SDM dari segi jumlah dan luas wilayah di Puskesmas Tamalanrea sudah cukup karena wilayah kerja Puskesmas Tamalanrea hanya mencakup satu kelurahan.

Hasil latar belakang pendidikan, sumber daya manusia pelaksana program pelayanan VCT mempunyai pendidikan yang sudah mencukupi yakni D3 dan S2 di bidang kesehatan. Hal ini sesuai dengan pedoman pelaksanaan konseling dan tes HIV bahwa tidak ada standar pendidikan yang harus dimiliki petugas pelayanan VCT yang terpenting sumber daya manusia untuk pelayanan VCT harus sudah terlatih dan memiliki ketrampilan dibidangnya masing-masing. Menurut penelitian Ledikwe (2013), sumber daya yang memadai dapat mempengaruhi pelaksanaan pelayanan VCT HIV dan AIDS.

Berdasarkan hasil penelitian mengenai pelatihan sumber daya manusia petugas pelayanan VCT diperoleh bahwa petugas sudah mendapatkan pelatihan dan dirasa cukup untuk menjalankan program pelayanan VCT di Puskesmas Lebdosari. Sumber daya untuk penyelenggaraan program VCT menurut panduan memang harus sudah terlatih. Selain itu berdasarkan wawancara mendalam kepada informan triangulasi terkait pelatihan VCT, pelatihan yang dilakukan sekali cukup untuk menjalankan program VCT. Penelitian ini sejalan dengan penelitian Balqis (2013) yang mengatakan bahwa petugas VCT selama ini sudah mendapatkan pelatihan, meskipun hanya sekali akan tetapi sudah merasa cukup. Hal ini berbeda dengan hasil penelitian yang dilakukan oleh Widiyasari (2014) bahwa pelatihan masih kurang karena belum semua bidan mendapatkan pelatihan VCT dan PMTCT. Seharusnya tenaga kesehatan yang terlibat dalam pelayanan HIV/AIDS harus mendapatkan pelatihan yang lebih spesifik dan secara khusus, karena pelayanan HIV/AIDS membutuhkan tenaga kesehatan yang berdedikasi dan mempunyai ketrampilan yang lebih.

Petugas program pelayanan VCT di Puskesmas Lebdosari mempunyai hambatan yang berkaitan dengan kemampuan petugas seperti mengalami kesulitan dalam mengisi siha karena adanya formulir vct yang tidak diisi lengkap dan adanya kegiatan rapat sehingga terjadi kerepotan dalam pelayanan. Hal ini berbeda pada penelitian yang dilakukan oleh Armanita (2008), hambatan operasional yang berkaitan dengan kemampuan petugas yaitu kurangnya skill konseling petugas sehingga mempengaruhi kemampuan dalam berkomunikasi. Penelitian lain yang dilakukan oleh Mahato (2013) hambatan sistemik keberlanjutan layanan VCT yaitu kurangnya staf dan pelatihan, pengawasan dan evaluasi tidak memadai, dan akses terbatas ke layanan bagi orang-orang yang tinggal di daerah pedesaan. Begitu juga dengan hasil penelitian dari Saputra (2015) tentang hambatan pelaksanaan JKN terkait SDM pelaksanaan pelayanan kesehatan di Kabupaten Tabalong yaitu kurangnya kuantitas SDM pelaksanaan pelayanan kesehatan dan distribusinya yang belum merata. Sedangkan penelitian dari Mahendradhata (2008) hambatan utama yang dirasakan oleh penyedia layanan diantaranya adalah komunikasi, pasien merasa tersinggung, dan stigmatisasi.

Berdasarkan hasil penelitian, diketahui bahwa tidak ada dana alokasi khusus untuk pelaksanaan program pelayanan VCT di Puskesmas Lebdosari. Karena semua kebutuhan utama VCT seperti reagen sudah dicukupi oleh Dinas Kesehatan. Adapun pasien yang melakukan pelayanan VCT tidak dikenakan biaya. Dana yang didapatkan puskesmas dari 
JKN, BOK ataupun APBD digunakan untuk pembiayaan kepentingan barang habis pakai. Hal ini sejalan dengan penelitian yang dilakukan oleh Prastiya (2016) pendanaan pelaksanaan layanan VCT sumbernya dari dinas kabupaten, karena obat dan reagen didropping semua dari dinas. Hasil penelitian lain dari Arikarni (2017) mengatakan bahwa anggaran atau dana yang berasal dari pemerintah daerah dalam menanggungani HIV dan AIDS di Kota Samarinda minim.

Dukungan dana perlu dilakukan dalam melaksanaan program pelayanan VCT. Adanya dana juga menjadi syarat untuk kelancaran sebuah program. Hasil penelitian Haya (2015) mengatakan kurangnya dukungan pemerintah dari segi pendanaan terhadap penanggulangan HIV/AIDS oleh Komisi Penanggulangan AIDS Kota Bontang menjadi kendala dalam pelaksanaan program Volountary Counseling Test Mobile.

Sarana merupakan kebutuhan penunjang dalam keberhasilan suatu program. Dalam pelaksanaan suatu program selalu membutuhkan berbagai sarana dan prasarana yang mendukung sehingga program tersebut dapat terlaksana sesuai dengan yang telah direncanakan. Selain itu, Rosdiana (2017) mengatakan bahwa setiap organisasi dalam menyelenggarakan kegiatannya membutuhkan sarana dan prasarana yang cukup dengan kualitas yang baik untuk mencapai tujuan yang diharapkan. Tanpa ketersedian sarana dan prasarana, suatu kegiatan tidak dapat diselesaikan sebagaimana seharusnya, bahkan akan mengalami hambatan atau tidak berjalan dengan lancar. Adapun sarana yang ada di Puskesmas Lebdosari meliputi papan nama/petunjuk pelayanan VCT, ruang tunggu, ruang konseling, dan ruang laboratorium. Berdasarkan hasil penelitian, jenis sarana dalam pelaksanaan program pelayanan VCT di Puskesmas Lebdosari sudah cukup lengkap, ketersediaan sarana yang ada dapat dikatakan memenuhi kebutuhan, dan kondisi dari sarana tersebut juga baik. Hal ini dapat dikatakan bahwa sarana yang ada di Puskesmas Lebdosari sudah sesuai dengan pedoman pelayanan VCT.
Selain itu, hasil penelitian ini sejalan dengan hasil penelitian lain yang dilakukan Sary (2009) yang menyebutkan bahwa sarana dan prasarana yang dibutuhkan dalam melaksanakan program HIV sesuai dengan pedoman VCT. Akan tetapi terdapat perbedaan dengan hasil penelitian Mujiati (2013) tentang sarana yang mengatakan bahwa sarana dan prasarana belum baik karena tidak ada tempat cuci tangan diruang pengambilan darah, dan tidak ada kotak saran di ruang tunggu.

Metode merupakan suatu cara untuk melaksanakan kegiatan tertentu. Dalam pedoman pelaksanaan program pelayanan VCT, metode yang dilakukan berupa mobile VCT dan VCT statis atau tetap. Berdasarkan hasil penelitian, petugas mengetahui metode pelaksanaan program pelayanan VCT, dan dalam pelaksanaannya program pelayanan VCT Puskesmas Lebdosari lebih sering menggunakan metode statis, dimana pasien datang ke puskesmas untuk melakukan pemeriksaan VCT seperti penjelasan dari informan triangulasi yang mengatakan bahwa saat melakukan pemeriksaan VCT datang langsung ke puskesmas, sedangkan untuk mobile VCT jarang dilakukan. Penelitian lain dari Katili (2014) tentang Studi Pelaksanaan Pelayanan Voluntary Counselling and Testing (VCT) HIV dan AIDS di Puskesmas Kota Makassar mengatakan bahwa di lima puskesmas penyedia pelayanan VCT HIV dan AIDS menerapkan model pelayanan statis dan mobile.

Program pelayanan VCT untuk dikenal dan diketahui oleh masyarakat membutuhkan sebuah market (pemasaran). Dalam pemasaran perlu adanya perencanaan dan bentuk strateginya, sehingga bisa berhasil mengajak masyarakat untuk memanfaatkan program tersebut. Berdasarkan hasil penelitian, perencanaan pemasaran program pelayanan VCT di Puskesmas Lebdosari tidak dilakukan secara khusus hanya pelaksanaan saja. Dari bagian promosi kesehatan hanya memenuhi target yang diberikan oleh dinas kesehatan bahwa dalam setahun ada 48 kali penyuluhan mengenai VCT yang masuk dalam materi HIV/AIDS, dan bagian promkes bekerja sama 
dengan lintas sektor seperti resos. Adapun bentuk strateginya yaitu melakukan penyuluhan, sosialisasi dan kerjasama antar lintas sektor serta biaya pelayanan yang gratis. Hasil penelitian ini berbeda dengan penelitian yang dilakukan oleh Prastiya (2016) mengenai promosi VCT, yang didapatkan bahwa belum ada upaya untuk melakukan promosi ke masyarakat sehingga belum begitu banyak masyarakat yang berada di wilayah kerja puskesmas datang untuk memeriksakan diri.

Perencanaan merupakan salah satu fungsi manajemen yang penting karena akan menentukan fungsi-fungsi manajemen lainnya. Perencanaan juga dapat diartikan sebagai proses mendefinisikan tujuan organisasi membuat strategi untuk mencapai tujuan itu dan mengembangkannya rencana kerja dari organisasi. Perencanaan yang baik akan menghasilkan sesuatu yang baik pula. Dalam perencanaan pelaksanaan program pelayanan VCT di Puskesmas Lebdosari sesuai hasil penelitian, tidak dilakukan perencanaan secara rinci hanya saja dengan membentuk petugas menjadi tim VCT dan membuat jadwal pelayanan. Pihak yang terlibat dalam penyusunan perencanaan yaitu bagian UKP dan UKM Puskesmas Lebdosari, karena program pelayanan VCT masuk dalam upaya keduanya. Adapun hasil penelitian dari Armanita (2008) mengatakan bahwa perencanaan VCT dilakukan oleh panitia khusus yang dibentuk oleh POKJA HIV RSKO.

Pengorganisasian dalam sebuah manajemen sangat dibutuhkan. Pengorganisasian adalah salah satu fungsi manajemen yang juga mempunyai peranan penting seperti halnya fungsi perencanaan. Melalui fungsi pengorganisasian, seluruh sumber daya yang dimiliki oleh organisasi (manusia dan yang bukan manusia) akan diatur penggunaannya secara efektif dan efisien. Pengorganisasian dapat membuat kejelasan dalam pembagian tugas dan wewenang sehingga tercipta keseimbangan. Berdasarkan hasil penelitian tentang pengorganisasian pada program pelayanan VCT di Puskesmas Lebdosari, terdapat seseorang yang menjadi koordinator untuk pelayanan VCT. Adapun pembagian tugas dan wewenang petugas dalam pelaksanaan program pelayanan VCT didasarkan pada petugas yang sudah mengikuti pelatihan VCT. Hal ini sejalan dengan penelitian yang dilakukan Badu (2016) tentang pengorganisasian yang mengatakan bahwa adanya pembagian tugas dan wewenang antara koordinator PONED dan anggota terdapat jam pelayanan yang jelas. Kesesuaian dalam pembagian tugas dan wewenang akan menjadikan sebuah program dapat berjalan lancar. Menurut Muninjaya (2004) dalam Armanita (2008), pembagian tugas yang dilakukan dengan jelas dan sesuai kemampuan staf maka akan berkembang menjadi kelompok kerja yang kompak dan dinamis. Adapun hasil penelitian yang dilakukan Armanita (2008) tentang pengorganisasian program VCT, pelimpahan wewenang dan tugas diakui belum berjalan optimal, sehingga terkadang satu orang mendapat tugas yang terlalu banyak.

Pada tahapan program pelayanan VCT di Puskesmas Lebdosari, petugas mengetahui tahapan-tahapan dari pelaksanaan pelayanan VCT, dan menjalankannya sesuai dengan pedoman. Dalam pedoman pelaksanaan pelayanan VCT (Depkes RI, 2008), tahapan yang dilakukan untuk pelayanan VCT yaitu konseling pre testing, testing HIV, dan konseling pasca testing. Pada tahapan konseling pre testing pasien bersama konselor mendiskusikan hal-hal yang terkait dengan informasi akurat dan lengkap tentang HIV/AIDS, perilaku beresiko, testing HIV dan pertimbangan yang terkait dengan hasil negatif atau positif. Tahap yang selanjutnya yaitu tahap testing HIV. Tahap testing HIV dalam VCT bertujuan untuk menegakkan diagnosis. Apabila hasil tes sudah diketahui maka tahapan yang dilakukan itu konseling pasca testing. Pada tahapan ini membantu pasien untuk memahami dan menyesuaikan diri dengan hasil tes. Hal ini sejalan dengan penelitian yang dilakukan Samaran (2013) bahwa bidan dari puskesmas yang program PMTCT baik telah melakukan langkah konseling pre tes, testing HIV dan konseling post test. 
Tabel 2. Jumlah Kunjungan Pasien VCT

\begin{tabular}{lccccrrc}
\hline Uraian & \multicolumn{7}{c}{ Bulan } \\
\cline { 2 - 8 } & Januari & Februari & Maret & April & Mei & Juni & Juli \\
\hline $\begin{array}{l}\text { Jumlah orang yang } \\
\text { berkunjung }\end{array}$ & 36 & 3 & 2 & 1 & 5 & 1 & 6 \\
$\begin{array}{l}\text { Jumlah orang yang } \\
\text { HIV positif }\end{array}$ & 1 & 0 & 1 & 1 & 0 & 0 & 0 \\
\hline
\end{tabular}

Prinsip dalam pelaksanaan program pelayanan VCT di Puskesmas Lebdosari yaitu tidak memaksakan pasien untuk melakukan pemeriksaan VCT. Hal ini sesuai dengan pedoman pelayanan VCT bahwa tes HIV dilakukan secara sukarela dan terjaga kerahasiaannya. Begitu juga dengan informan triangulasi yang mengatakan bahwa saat melakukan pemeriksaan VCT tidak ada paksaan melainkan atas inisiatif sendiri. Hasil penelitian yang dilakukan oleh Katili (2014) yang berkaitan dengan tahapan pelayanan VCT pada pelaksanaan pelayanan VCT di Puskesmas Kota Makassar juga dihasilkan bahwa tahapan pelayanan VCT sesuai dengan pedoman.

Sebuah program yang telah berjalan perlu adanya kegiatan evaluasi. Kegiatan evaluasi ini dimaksudkan untuk mengetahui sejauh mana pencapaian program tersebut. Evaluasi kegiatan yang dilakukan pada pelaksanaan program pelayanan VCT di Puskesmas lebdosari semarang hanya dilakukan dengan pembuatan laporan setiap bulan. Kegiatan evaluasi yang berupa laporan tiap bulan tersebut meliputi jumlah kunjungan pasien dan hasil dari pemeriksaan VCT. Hal ini sejalan dengan penelitian Armanita (2008) yang mengatakan bahwa evaluasi program VCT berupa laporan tertulis yang dilakukan setiap bulan. Kegiatan evaluasi sebuah program perlu untuk dilakukan, karena untuk memperbaiki pelayanan konseling VCT maka diperlukan optimalisasi peran monitoring dan evaluasi. Menurut Praditya (2012) hasil evaluasi dapat digunakan untuk perbaikan pelaksanaan manajemen kedepan. Selain itu, kegiatan evaluasi juga bermanfaat untuk perbaikan mutu dan dapat dijadikan untuk mengambil keputusan atau melakukan tindak lanjut dari program yang telah dilaksanakan.
Output merupakan hasil dari suatu kegiatan atau program yang dilakukan. Pada program pelayanan VCT di Puskesmas Lebdosari, output yang didapatkan berdasarkan penelitian yaitu jumlah pasien yang melakukan kunjungan pelayanan VCT.

Berdasarkan tabel 2, jumlah pasien yang melakukan kunjungan pelayanan VCT dalam beberapa bulan terakhir terhitung dari Bulan Januari s.d Juli 2017 cenderung mengalami penurunan, hanya mengalami kenaikan pada Bulan Mei dan Juli. Hasil ini tidak mempengaruhi target dalam penerimaan jumlah pasien VCT, karena pada program pelayanan VCT di Puskesmas Lebdosari tidak ada standar target yang ditetapkan. Hal ini berbeda dengan penelitian yang dilakukan oleh Muhith (2012) bahwa ada target dalam menerima pasien VCT yakni $80 \%$ dari keseluruhan WBP dan Penasun dapat mengakses VCT, akan tetapi hasil yang didapatkan masih dibawah target yang telah ditentukan. Sehubungan dengan hal tersebut, seseorang yang mengikuti VCT dapat berdampak pada pola perilaku dalam hidupnya. Seperti penelitian yang dilakukan Anita (2016) yang mengatakan bahwa terdapat perubahan sikap yang bermakna antara transgender yang mendapatkan VCT dibandingkan transgender yang tidak mendapatkan VCT.

\section{PENUTUP}

Berdasarkan hasil penelitian, dapat disimpulkan bahwa Sumber daya manusia dalam pelaksanaan program pelayanan VCT di Puskesmas Lebdosari jumlahnya sudah cukup, latar belakang pendidikan petugas sudah sesuai, dan petugas yang melaksanakan VCT sudah mendapatkan pelatihan, tidak ada dana alokasi khusus untuk pelaksanaan program pelayanan VCT, sarana dalam pelaksanaan program 
pelayanan VCT cukup lengkap dan kondisinya dalam keadaan baik, petugas pelaksana program pelayanan VCT mengetahui metode pelayanan VCT dan pelaksanaannya cenderung menggunakan metode VCT statis, pemasaran yang dilakukan dalam pelaksanaan program pelayanan VCT yaitu dengan melakukan penyuluhan, sosialisasi dan kerjasama antar lintas sektor namun tidak ada perencanaan pemasaran secara khusus, perencanaan program pelayanan VCT di Puskesmas Lebdosari dilakukan oleh bagian UKM dan UKP tetapi tidak dilakukan perencanaan secara rinci, hanya pelaksanaan saja, pembagian tugas dan wewenang dalam pengorganisasian program pelayanan VCT dilakukan berdasarkan petugas yang mengikuti pelatihan, tahapan pelayanan dari program pelayanan VCT sudah dilakukan sesuai dengan pedoman, evaluasi yang dilakukan hanya sebatas laporan, dan jumlah kunjungan pasien dalam beberapa bulan terakhir cenderung mengalami penurunan.

Saran yang dapat diberikan bagi peneliti selanjutnya yang akan melakukan penelitian yang serupa dapat menggali informasi lebih dalam mengenai pelaksanaan program pelayanan VCT agar nantinya data yang diperoleh lebih kompleks.

\section{DAFTAR PUSTAKA}

Anita dan Magfirah. 2016. Pengaruh VCT HIV/AIDS terhadap Perubahan Sikap Seksual pada Kalangan Transgender di Banda Aceh. Idea Nursing Journal, 7(2): 71-75

Arikarni. 2017. Implementasi Peraturan Daerah Kota Samarinda Nomor 03 Tahun 2009 tentang Pencegahan dan Penanggulangan HIV dan AIDS oleh Komisi Penanggulangan AIDS Kota Samarinda (Studi tentang Penanggulangan HIV dan AIDS di Kota Samarinda). eJournal Administrasi Negara, 5(2): 5974-5986

Armanita, R. Y. 2008. Gambaran Manajemen Program Konseling dan Tes Sukarela HIV/AIDS Rumah Sakit Ketergantungan Obat (RSKO) Jakarta Tahun 2008. Skripsi. Universitas Indonesia

Badu, F. D. dan Saleh, F. 2016. Gambaran Manajemen Pelayanan Obstetri Neonatal Emergensi Dasar (PONED) di Puskesmas
Tibawa Kabupaten Gorontalo. Promotif, 6(2): 109-117

Balqis, Satriani dan Nurhayani. 2013. Studi Mutu Pelayanan Voluntary Counseling and Testing (VCT) dI Puskesmas Jongaya Makassar. Jurnal MKMI, 9(4): 243-249

Depkes RI. 2008. Pedoman Pelayanan Konseling dan Testing HIV/AIDS secara Sukarela (Voluntary Counselling and Testing). Jakarta

Dinas Kesehatan Kota Semarang. 2015. Profil Kesehatan Kota Semarang Tahun 2015. Semarang: Dinas Kesehatan Kota Semarang

Dinas Kesehatan Provinsi Jawa Tengah. 2015. Profil Kesehatan Provinsi Jawa Tengah Tahun 2015. Semarang: Dinas Kesehatan Provinsi Jawa Tengah

Findarti, F. R. 2016. Pengaruh Pengembangan Sumber Daya Manusia terhadap Kinerja Pegawai pada Kantor Badan Kepegawaian Daerah Provinsi Kalimantan Timur. eJournal Ilmu Administrasi Bisnis, 4(4): 937-946

Haya, D. A. 2015. Pelaksanaan Program Volountary Counseling Test Mobile dalam Rangka Penanggulangan HIV/AIDS oleh Komisi Penanggulangan AIDS Kota Bontang. eJournal Administrasi Publik, 3(4): 1265-1279

Katili, S. C. A. S., Amiruddin, R. dan Ansariadi. 2014. Studi Pelaksanaan Pelayanan Voluntary Counselling and Testing (VCT) HIV dan AIDS di Puskesmas Kota Makassar. Jurnal MKMI, 1(1): 1-12

Kementerian Kesehatan RI. 2016. Profil Kesehatan Indonesia Tahun 2015. Jakarta: Kementerian Kesehatan RI

Ledikwe, J. H., Kejelepula, M., Maupo, K., Sebetso, S., Thekiso, M., Smith, M., Mbayi, B., Houghton, N., Thankane, K., O'Malley, G. dan Semo, B. 2013. Evaluation of a WellEstablished Task-Shifting Initiative: The Lay Counselor Cadre in Botswana. Plos One, 8(4): $1-10$

Mahato, P. K., Bi, P. dan Burgess, T. 2013. Voluntary Counseling and Testing (VCT) services and its role in HIV/AIDS prevention and management in Nepal. South East Asia Journal of Public Health, 3(1): 10-16

Mahendradhata, Yodi., Ahmad, R. A., Lefèvre, P., Boelaert, M. dan Stuyft, P. V. D. 2008. Barriers for introducing HIV testing among tuberculosis patients in Jogjakarta, Indonesia: a qualitative study. BMC Public Health 2008, 8(385): 1-10

Muhith, A., Prasetyaning, L. Dan Nursalam. 2012. 
Voluntary Counseling and Testing (VCT) HIV-AIDS pada Tahanan di Rumah Tahanan Negara Kelas I Surabaya. Jurnal Ners, 7(2): 116-120

Mujiati, Sugiharti dan Isakh, B. M. 2013. Gambaran Pelaksanaan Layanan Voluntary Counseling and Testing (VCT) dan Sarana Prasarana Klinik VCT di Kota Bandung Tahun 2013. Jurnal Kesehatan Reproduksi, 4(3): 153-160

Praditya, O. 2012. Studi Kualitatif Manajemen Pengelolaan Sampah di Kelurahan Sekaran Kota Semarang. Unnes Public Health Journal, 1(2): 1-7

Prastiya, I. M. A. 2016. Kesiapan Puskesmas 1 Negara dalam Menanggulangi Peningkatan Kejadian Kasus HIV/AIDS di Kabupaten Jembrana Bali 2014. E-Jurnal Medika, 5(4): 110

Rosdiana, A. I., Raharjo, B. B. dan Indarjo, S. 2017. Implementasi Program Pengelolaan Penyakit Kronis (Prolanis). HIGEIA, 1(3): 140-150

Samaran E., Shaluhiyah, Z. dan Sriatmi, A. 2013. Implementasi Program Penjaringan "Prevention of Mother to Child Transmission of HIV" (PMTCT) oleh Bidan di Puskesmas Wilayah Kerja Dinas Kesehatan Kota Sorong Provinsi Papua Barat. Jurnal Manajemen Kesehatan Indonesia, 01(03): 206-215

Saputra, M., Marlinae, L., Rahman, F. dan Rosadi D. 2015. Program Jaminan Kesehatan Nasional dari Aspek Sumber Daya Manusia
Pelaksana Pelayanan Kesehatan. KEMAS, 11 (1): $32-42$

Sari, Y. M. 2013. Evaluasi Pelaksanaan Program Pemberantasan Penyakit DBD (P2DBD) di Wilayah Kerja Puskesmas Tamalanrea Makassar. Jurnal MKMI, 9(2): 125-132

Sary, L. 2009. Analisis Pelaksanaan Strategi Pelayanan Provider Initiated HIV Testing and Counseling / PITC (Studi Kasus Di Balai Kesehatan Paru Masyarakat Semarang). Jurnal Promosi Kesehatan Indonesia, 4(2): 86-93

Usnawatig, U. dan Zaenafree, I. 2013. Studi Kualitatif Motivasi Wanita Pekerja Seks (WPS) di Sepanjang Ruas Jalan Stasiun Poncol untuk Mengikuti Program Voluntary Counselling and Testing (VCT). Unnes Journal of Public Health, 2(4): 1-12

Widiyasari, Eny., Shaluhiyah, Z. dan Margawati. A. 2014. Implementasi Integrasi Program Prevention of Mother to Child HIV Transmission (PMTCT) dengan Layanan Antenatal di Puskesmas Wilayah Kota Surabaya. Jurnal Manajemen Kesehatan Indonesia, 02(01): 10-18

Yuriati, P., Handayani, O. W. K. dan Rustiana, E. R. 2016. Evaluasi Pelaksanaan Kegiatan Prevention of Mother To Child Transmission (PMTCT) pada Ibu Hamil di Kota Tanjungpinang. Public Health Perspective Journal, 1(1): 243-249 